Spring 2009

\title{
Not Just Mexico's Problem: Labor Migration from Mexico to the United States (1900 - 2000)
}

Ruth Gomberg-Muñoz

Loyola University Chicago, rgombergmunoz@gmail.com

Follow this and additional works at: https://ecommons.luc.edu/anthropology_facpubs

Part of the Anthropology Commons

\section{Recommended Citation}

Gomberg-Muñoz, R. "Not Just Mexico's Problem: Labor Migration from Mexico to the United States (1900

- 2000)." The Journal of Latino-Latin American Studies, Volume 3, Number 3, Spring 2009, pp. 2-18.

This Article is brought to you for free and open access by the Faculty Publications and Other Works by Department at Loyola eCommons. It has been accepted for inclusion in Anthropology: Faculty Publications and Other Works by an authorized administrator of Loyola eCommons. For more information, please contact ecommons@luc.edu. cc) (i) $\Theta$

This work is licensed under a Creative Commons Attribution-Noncommercial-No Derivative Works 3.0 License. (c) University of Nebraska-Omaha, 2009. 


\title{
Not Just Mexico's Problem: Labor Migration from Mexico to the United States $(1900$ - 2000)*
}

\author{
Ruth Gomberg-Muñoz \\ University of Illinois-Chicago
}

\begin{abstract}
:
U.S. President Barack Obama has vowed to "help countries like Mexico... do a better job of creating jobs for their people" as part of his plan to curtail undocumented immigration to the United States (Organizing for America). This idea - that the root cause of undocumented migration from Mexico to the U.S. is economic underdevelopment in Mexico - has currency in both popular and political discourse. But is it accurate? In this article, I synthesize historical, theoretical, and ethnographic scholarship to provide a transnational perspective on twentieth century labor migration from Mexico to the United States. These data show that "illegal" transmigrant labor is not an historical accident, nor merely an unfortunate side effect of legal migration, nor a result of economic underdevelopment in Mexico. Rather, undocumented transmigration is a predictable result of the confluence of three interrelated trends: neoliberal development of the Mexican and U.S. economies, the establishment of transnational social networks over time, and gross disparity between U.S. immigration policy and the realities of labor needs within global capitalism. Political rhetoric that deems unauthorized migration as "Mexico’s problem" obscures this economic interdependence, conceals the ways in which development policies have produced itinerant wage labor, and masks the complicity of U.S. policies in encouraging and sustaining undocumented labor migration.

Furthermore, rhetoric that distances U.S. policy from labor migration reinforces the marginalization of some estimated 12 million undocumented immigrants in the United States.
\end{abstract}

Keywords: Mexican immigration, history, labor markets, political rhetoric, discrimination, global capitalism

\section{Introduction}

Ebbs and flows in Mexican migration to the U.S. correspond not with economic underdevelopment or stagnation, but with the vagaries of neoliberal economic development itself. This article will review the history of Mexico-U.S. labor migration using phases in Mexico’s political economy as a guide. This history begins with the first steps toward modernization established at the turn of the twentieth century by Porfirio Diaz and ends at the present period. At every juncture, I address the political and economic trends of the period, the impact of these trends on Mexican workers and agrarians, major patterns of movement and demographic characteristics of migrants, and the implications of the period for future migrations.

*Parts of the present article are included in my forthcoming book, Labor and Legality: Life in a Mexican Immigrant Network that is scheduled for release by Oxford University Press in the Fall of 2010

The Journal of Latino-Latin American Studies, Volume 3, Number 3, spring 2009, pp. 2-18 
I also discuss the social and political trends in the United States that shape the direction, flow, and perceptions of labor migration from Mexico. Finally, I examine how political rhetoric surrounding transmigration has produced a politics of exclusion in the United States, and I consider the implications of this exclusion for current and future Mexican workers in the U.S.

\section{6 - 1910: El Porfiriato}

In 1860, about half of rural Mexico was controlled by ejidos, corporate local communities engaged in subsistence and local-market production (Weaver 2000, 51). By the end of the thirtyfour year reign of President Porfirio Diaz (1876-1910), 5 million rural Mexican had lost their land rights (Pedraza and Rumbaut 1996, 254); by 1910 less than 5\% of rural households retained control over land and large haciendas increasingly dominated the countryside (Cardoso 1980, 7). The development strategy of Porfirio Diaz was based on liberal economic policies that promoted direct foreign investment in Mexico's agriculture, industry, mining, petroleum, and infrastructure (Kirkwood 2000: Massey et al. 2002). Capital investment in agriculture accelerated production, and the new large-scale plantations converted cultivation from subsistence goods for local markets to cash-crops for export (Cardoso 1980; Kirkwood 2000; Massey et al. 2002).

The impact of liberal development on Mexico’s peasantry was manifold. Without land, peasants were no longer self-sufficient in food. Mechanization of agricultural production reduced the demand for labor and further depressed wages for sharecroppers on the large haciendas, a main source of work for landless peasants (Cardoso 1980). Domestic craft production was undermined by the introduction of mass-produced wares to local markets (Massey 1988; Massey et al. 2002). Simultaneously, the costs of living had increased because Mexico was now importing basic foodstuffs (Massey et al. 2002). The penetration of capital development into rural Mexico destabilized traditional communal subsistence practices (Foster 1979 [1967]) and, through the new railroads, provided cheap access to industrializing centers in the cities (Cardoso 1980). Mexico’s burgeoning urban sector swelled with rural migrants after 1900. While only $9.3 \%$ of the Mexican population lived in urban areas in 1900, that number had grown to $15.6 \%$ by 1930 (Weaver 2000, 129). Large reserves of displaced labor put downward pressure on wages in the cities, resulting in violent labor strikes between 1905 and 1910 (Kirkwood 2000; Massey et al. 2002, 30).

The railroads had an additional impact on rural Mexico: they provided labor recruiters from the United States with passage into Mexico’s interior (Cardoso 1980; Cornelius 1981; Gutierrez 1995). As Mexico’s industrial labor market quickly became saturated, growers in the southern and western United States found themselves experiencing a severe labor shortage brought on by restrictive immigration policies that cut off migrant labor supplies from Asia in 1907 (Gutierrez 1995; Massey et al. 2002). Labor recruiters (enganchadores) used the new rail system to travel from the southwest U.S. into the fertile west-central states of Guanajuato, Jalisco, Michoacan, and Zacatecas (the region known as el Bajío), where they employed notoriously coercive means of recruiting workers to go north. This system came to be known as el enganche (the hook) because recruiters "hooked" peasants with false expectations and promises of great rewards, when in reality the work conditions better resembled indentured servitude (De Genova and Ramos-Zayas 2003; Gutierrez 1995; Massey et al. 2002).

As wages declined and the cost of food increased, more Mexicans headed over the northern border in search of work (Cardoso 1980). The shift toward industrialization that was established during the Porfiriato mobilized what can be considered the first real stage of Mexican labor migration (Cardoso 1980; Massey 1988). The Mexican-born population in the

The Journal of Latino-Latin American Studies, Volume 3, Number 3, spring 2009, pp. 2-18 
United States, approximately 68,000 people in 1880, grew by about 10,000 between 1880 and 1890, then surged by 50,000 over the following decade (Gutierrez 1995, 45). Between 1900 and 1910, over 100,000 Mexican migrants arrived in the United States (Gutierrez 1995, 45). These early migrants tended to come from rural west-central Mexico, an area that had the distinction of being more densely populated than the northern desert regions and being within the reach of both industrialization and labor recruiters from the U.S. (Cardoso 1980; Durand et al. 2001; Fussell 2004). Although emigration to the United States was comparatively slight during this period, the Porfiriato set into motion migration patterns that are detectable to this day (Portes 2004).

When it ended in 1848, the Mexican-American war had been the deadliest and costliest war in American history (Gutierrez 1995). According to the stipulations of the Treaty of Guadalupe Hidalgo, Mexico ceded its entire northern province to the United States, along with the 75,000 to 100,000 Mexicans who resided there (De Genova and Ramos Zayas 2003; Gutierrez 1995, 13). Perhaps still bitter over the war, Anglo-Americans regarded these ethnic Mexicans with derision and steadily relegated them to an inferior "caste-like" status in (what had become) the Southwest United States' developing social structure (Cardoso 1980; De Genova and Ramos-Zayas 2003; Gutierrez 1995; Pedraza and Rumbaut 1996). The influx of gold prospectors in California in the early 1850s forced many Mexican Californios from the goldfields, and Mexican Americans throughout the Southwest were steadily displaced from their lands, subject to massive civil rights violations, and forced into low-wage, low-status work in agriculture, mining, and construction (De Genova 2005; Gutierrez 1995). Mexicans were racially segregated from whites in housing, schooling, and public facilities throughout the southwest (Gutierrez 1995; Menchaca and Valencia 1990). Segregationist legislation was justified by a doctrine of white racial supremacy that cast Mexicans as simple-minded racial "hybrids" of inferior caste to white Americans (Cardoso 1980; Menchaca and Valencia 1990; Pedraza and Rumbaut 1996). By the turn of the $20^{\text {th }}$ century, occupational discrimination had become institutionalized into a dual-wage system, in which Mexican workers were consistently paid less than their white counterparts (Gutierrez 1995; Hondagneu-Sotelo 1994).

\section{0 - 1929: Revolution and Reconstruction}

The Porfiriato came to a sudden and bloody end with the Mexican Revolution (1910-1917). The Mexican Revolution displaced large numbers of people, crippled the economy and led some 200,000 Mexicans to seek refuge in the United States (Kirkwood 2000; Massey et al. 2002, 30). The Revolution was stimulated by developmental policies of the Porfiriato that had depressed living conditions in both rural and urban areas. Angry peasants and workers demanded land and labor reform and, although the new regime was hardly revolutionary, they received important concessions (Cardoso 1980; Kirkwood 2000).

Industrialization and economic growth resumed after the end of the Revolution in 1917 and continued apace until the Great Depression. Post-revolution presidents Alvaro Obregón (1920-1924) and Plutarco Elias Calles (1924-1928) returned to the liberal economic policies initiated by Diaz (Kirkwood 2000). Despite the nationalist language of the 1917 constitution, the country grew increasingly dependent on foreign capital investment under duress of sustained pressure from the United States (Kirkwood 2000). In 1929 alone, the U.S. invested 3 billion pesos in Mexico and received 70 - 80 percent of Mexico's exported goods (Kirkwood 2000, 163). Mexico used this capital to develop infrastructure and industry and to construct a massive irrigation system that expanded arable land, particularly in the north and the west-central states of the Bajío (Kirkwood 2000).

The Journal of Latino-Latin American Studies, Volume 3, Number 3, spring 2009, pp. 2-18 
In the decade following the Revolution, land redistribution was minimal - only 3 million acres had been returned to ejidos while 320 million acres were still controlled by haciendas (Kirkwood 2000, 159). Battles over land ensued in the countryside; well-armed hacendados routinely and violently repressed peasant uprisings and continued to dominate agricultural production (Cardoso 1980). In the cities, nascent labor unions were also suppressed and labor conflicts persisted (Kirkwood 2000). Mexico continued to have a large supply of mobile wage seekers. Mexican emigration surged during the 1920s, boosted by restrictions on European and Asian immigrants to the U.S., a booming U.S. economy, and vast wage differentials between the United States and Mexico (Cardoso 1980; Durand et al. 2001; Massey et al. 2002).

Between 1910 and 1930 over a million Mexican nationals (one tenth of Mexico's total population) emigrated to the United States (De Genova and Ramos-Zayas 2003; Gutierrez 1995, 40). The greatest proportion of these migrants came from the west-central states of Guanajuato, Jalisco, Michoacan, and Zacatecas, where modernization had had its greatest impact (Durand et al. 2001; Fussell 2004; Gamio 1929). Mexican immigrants worked in a variety of American industries; including agriculture, mining, railroad construction, and auto and steel manufacture (Gutierrez 1995, 45). By the 1920s, Mexican workers (both migrants and Mexican Americans) constituted as much as 75 percent of the agricultural workforce in California and the unskilled construction labor force in Texas (Gutierrez 1995, 34). Migration was predominantly temporary and characterized by high rates of return migration and remittance; Gamio (1929) estimated that 5 million dollars in remittance money circulated between Mexico and the U.S. annually during the 1920s. Labor migration to the U.S. was a strategy employed by agrarians seeking to increase the productivity of their land back home with capital investments (Massey et al. 1998; Massey et al. 2002). Despite growing American nativism and the establishment of the U.S. Border Patrol in 1924, Mexican migration to the United States reached unprecedented levels and remained high until the onset of the Great Depression (Massey et al. 2002). By the 1930s, emigration had been established as a viable economic strategy for large numbers of northern and west-central Mexicans (Pedraza and Rumbaut 1996).

After the turn of the century, the influx of Mexican migrant workers established the differentiation of Mexican labor in the minds of industrialists, growers, and their lobbyists in the Southwest United States (Cardoso 1980; Pedraza and Rumbaut 1996) Ironically, the fodder of negative stereotypes about Mexicans - docility, tractability, uncleanliness - came to be seen as great virtues of a low-wage labor force. During the immigration hearings of the early twentieth century, Mexicans were repeatedly identified as a labor force whose racial characteristics made them ideally suited for arduous and low-paying work (Gutierrez 1995; Pedraza and Rumbaut 1996). By 1930, the U.S. Census Bureau officially established "Mexican" as a distinct racial category (De Genova 2005, 221) and throughout the 1930s, criminalization and deportation of Mexicans was explicitly based on race and not citizenship (De Genova and Ramos-Zayas 2003, 5; Pedraza and Rumbaut 1996).

Prior to this period, ethnic Mexicans, on both sides of the border, self-identified with region and social class in favor of a Mexican-oriented identity (Gutierrez 1995). After the war, in response to discrimination and displacement, Mexican Americans began to shift from local allegiances to a more general ethnic solidarity (Garcia 1985; Gutierrez 1995). As with earlier southern and eastern European immigrants, Mexican immigrants from disparate backgrounds learned to think of themselves as Mexicans by being treated as such throughout the Southwest (Gutierrez 1995; Portes and Rumbaut 1996, 104). Within the Mexican barrios that sprang up throughout the Southwest, ethnic Mexicans sought to shield themselves from the affront of

The Journal of Latino-Latin American Studies, Volume 3, Number 3, spring 2009, pp. 2-18 
discrimination and harassment (Pedraza and Rumbaut 1996). Mexican Americans spoke their native Spanish and continued to observe Roman-Catholicism and Mexican cultural practices (Gutierrez 1995). Shut out from Anglo institutions and relegated to the bottom of the labor market, many Mexican communities established “mutualistas," mutual-aid organizations that pooled resources to fund events and provide insurance for households facing hardship (Gutierrez 1995; Portes and Rumbaut 1996). A Mexican ethnic identity was fostered by attempts of the Mexican government to reach out politically to "México de Afuera" (Mexico of the Outside) and was promoted in popular Spanish-language newspapers in the Southwest (Garcia 1995, 198-199; Pedraza and Rumbaut 1996). By the turn of the century, a sense of identity had emerged that bound Mexicans on both sides of the border as members of la Raza, a people with spiritual and blood ties rooted in ethnic Mexican-ness (Garcia 1985; Gutierrez 1995). Emergent ethnic enclaves among Mexican American and newly arrived Mexican migrants had two important implications for Mexican identity: they provided protection and a source of self-esteem in the face of racial subjugation and maintained Mexican cultural practices in barrios and ranchos throughout the American Southwest (Garcia 1985; Gutierrez 1995).

\section{The Decade of the 1930s}

Mexican emigration to the United States came to a virtual halt during the 1930s. Mexico's economy felt the shocks of the Great Depression as demand for exported goods declined and foreign investments in Mexico’s mining and oil industries dwindled (Kirkwood 2000). In 1934, the new President Lázaro Cárdenas (1934-1940) instituted recovery measures that set the stage for a period of sustained political stability and economic growth. The program of land redistribution, promised at the end of the Revolution, accelerated under Cárdenas, whose administration confiscated some 45 million acres of land from hacienda owners and allocated it to agrarian families (Massey et al. 2002, 34). To buffer the Mexican population from the effects of the Great Depression, the Cárdenas administration instituted substantial social reform, including protection for local producers in the form of import tariffs, foreign exchange controls, and labor codes to legalize unions, nationalization of the railroad and oil industries, and social welfare programs (Kirkwood 2000; Weaver 2000). In addition, Cárdenas consolidated rural and urban labor groups under a single political party, the PRI (Partido Revolucionario Institucional), ushering in an unprecedented period of political stability (Kirkwood 2000). Perhaps most importantly, Cárdenas established a policy of import substitution industrialization (ISI), which created internal markets in Mexico and reduced Mexico's dependence on imported goods (Kirkwood 2000; Massey 1988).

Meanwhile, Mexican émigrés in the United States were being sent home. The number of Mexican nationals counted by the U.S. census declined nearly 50 percent between 1930 and 1940 (Massey 2002, 34). At least 415,000 Mexicans were deported (some U.S. citizens as well as migrants) and another 85,000 were "voluntarily" repatriated (De Genova and Ramos-Zayas $2003,5)$. The promise of land redistribution combined with social supports and labor reform in Mexico, and the forcible removal of Mexicans in the United States, slowed international Mexican migration.

1940-1970: The Breadbasket and the Bracero Program

The Journal of Latino-Latin American Studies, Volume 3, Number 3, spring 2009, pp. 2-18 
The decades of the Bracero program were characterized by impressive rates of economic growth in Mexico. From 1940 to 1970, Mexico's economy grew at an average of 6 percent per year (compared to the United States' mere 4.8 percent growth rate) (Massey et al. 2002:35-36; Weaver 2000 129) and industrial and agricultural production grew 120 percent and 100 percent, respectively. This sustained period of substantial growth came to be dubbed the "Mexican economic miracle” (Massey et al. 2002, 36; Weaver 2000, 129). The population of Mexico doubled from 1934 to 1958, growing from 16 to 32 million (Kirkwood 2000, 184). The health, education, and life-expectancy of Mexico’s population also grew dramatically as Mexico transformed into a relatively wealthy, urban nation (Krauze 1997; Weaver 2000, 130). By the 1970s, over half of Mexicans lived in cities with populations of 20,000 or more (Marcelli and Cornelius 2001; Weaver 2000, 129).

Agricultural investment and industrialization became a priority once again during the tenure of President Miguel Alemán (1946-1952). Government investment in agriculture rose to 20 percent, agricultural production grew at a rate of 8 percent, and agricultural exports rose from 44.3 percent to 55.7 percent of total exports (Krauze 1997, 541-542). The Bajío, which spans Mexico’s traditional “migrant sending” states of Guanajuato, Jalisco, Zacatecas, and Michoacan, underwent significant agricultural modernization and the region came to be known as the “breadbasket of Mexico” (Roberts 1982, 309) Ironically, land redistribution actually exacerbated migration, as agrarians sought wage work to attain the financial capital that they needed to make their agricultural output competitive (Cornelius 1989; Massey et al. 1998; Massey et al. 2002; Roberts 1982). International migration was thus an important seasonal strategy for west-central farmers seeking supplemental income to bolster their lands' productivity, a task that increasingly required capital input. Peasants from Mexico’s isolated and impoverished southern regions tended to migrate from rural areas to regional urban centers and Mexico City (Arizpe 1980; Cohen 2004; Wright 1990) and constituted a small proportion of international migrants. Despite high rates of economic growth, labor markets in Mexico's industrial sectors could not absorb the continued migration of workers from rural areas and labor struggles continued to affect the cities (Kirkwood 2000). Migration to the U.S. became an essential “safety valve” for Mexico’s massive labor reserves (Cardoso 1983; Kirkwood 2000, 176).

In 1942, Mexico signed a binational treaty with the United States that allowed for temporary Mexican migration. The Bracero Program was a contract labor program designed to fulfill the labor needs of the U.S.'s powerful agricultural growers and relieve the pressure of Mexico's large wage-seeking population. Nearly five million Mexican workers crossed the border as braceros between 1942 and 1965, joined by large numbers of undocumented migrants from the 1950s onward (Massey 1988; Massey et al. 2002). According to some estimates, as many as four undocumented workers entered for every documented bracero (De Genova and Ramos-Zayas 2003, 5). The west-central plateau states continued to be over-represented in the migrant population, while isolated northern and southern regions supplied only a small proportion of migrant workers (Cohen 2004; Durand et al. 2001; Fussell 2004). The southern state of Oaxaca, for example, represented only 2.9 percent of the bracero labor force (Cohen 2004, 60).

The concept of Mexicans as a laboring class of the United States became institutionalized with the Bracero Program in the mid-twentieth century. The importation of Mexican labor drove deep splits within the Mexican American community (Garcia 1985; Gutierrez 1995). Many Mexican Americans, particularly those who had served in World War II, saw themselves at the threshold of (finally) attaining the "American Dream" and were concerned that an influx of 
“peasant” contract laborers would ruin Mexican Americans' newly won social standing (Garcia 1985; Gutierrez 1995). Others, including labor organizers and community activists, began to speak out against what they viewed as the exploitative nature of immigration and labor policies concerning Mexicans (Gutierrez 1995, 156). The connection between migrant labor, political powerlessness, and economic exploitation was made explicit in the comments of Mexican American activist Ernesto Galarza: "The Mexicans are in no position to bargain for wages with corporations. They do not speak English. They are completely ignorant of any legal obligations that employers may have. They cannot file claims... They cannot invoke the protection of the Mexican consuls. They are, in short, perfect strike breakers” (in Gutierrez 2003, 157-158). While some activists, including Galarza, recognized the racial character of exploitative treatment of migrant workers, many Mexican Americans looked down upon their Mexican-born counterparts as poor peasants and cheap laborers who, by taking jobs from native workers, undermined the socioeconomic well-being of the Mexican American community as a whole (Garcia 1985). The farmworkers union predominantly made up of Mexican American and Filipino laborers, ultimately played a decisive role in ending the Bracero Program (De Genova 2005).

The Bracero Program had important and enduring implications for Mexican labor migration to the United States. First, millions of Mexican workers became accustomed to employment practices, lifestyles, and consumption patterns in the U.S. Second, Mexican laborers and U.S. employers became increasingly economically interdependent. Third, migrant workers established networks between jobs in the U.S. and friends and family members back home; employers soon learned that tapping into these informal networks could save them the money and time investments that the Bracero program required (Massey et al. 2002). In spite of temporary reductions in undocumented passage due to border enforcement projects (i.e. “Operation Wetback" in 1954); the networks established during the Bracero program allowed undocumented migratory flows to become self-sustaining in the following decades (Calavita 1994; Cardoso 1983; Fussell 2004; Massey et al. 2002; Portes 2004).

The divide between Mexican migrants and Mexican Americans was substantially reduced in 1954 by "Operation Wetback," a high-profile campaign to repatriate undocumented workers that targeted Mexican communities in the Southwest (Gutierrez 1995; see Massey et al. 2002). Mexican households were torn apart, businesses disrupted, and all ethnic Mexicans, citizens and “illegals” alike were subject to heightened anti-Mexican sentiment and deportation (Gutierrez 1995). Many were angry, not only at the explicit racial orientation of the sweeps, but at the apparent hypocrisy of the U.S. government which was "perpetuating the political powerlessness of ethnic Mexicans by condoning the use of Mexican labor while simultaneously whipping up anti-immigrant hysteria against wetbacks” (Gutierrez 1995, 168). In fact, the motive of Operation Wetback was not to reduce Mexican migration but to funnel it through the Bracero Program, creating pressure on the Mexican government to extend the program and giving the appearance to the American public that the border was "under control." In a tag-team effort, the INS arrested migrant workers in the U.S. and transported them across the border where Department of Labor officials were waiting to process the deportees and send them back as braceros (Gutierrez 1995; Massey et al. 2002).

For Mexican Americans who had been touting the virtues of assimilation and U.S. citizenship, the explicitly racist and exploitative nature of immigration policies, and the persistence of segregationist practices, came as a blow (Gutierrez 1995; Portes and Rumbaut 1996). In the 1950s, political campaigns and organizations began to emerge in Mexican communities that encouraged cooperation between Mexican Americans and migrants.

The Journal of Latino-Latin American Studies, Volume 3, Number 3, spring 2009, pp. 2-18 
Increasingly, Mexican Americans came to believe what Mexican migrants had been saying for a century: that citizenship wasn’t important since Americans discriminated equally against all ethnic Mexicans (Gutierrez 1995). Emergent solidarity between Mexican Americans and Mexican nationals laid the foundations for unprecedented political activism in Mexican communities throughout the 1960s.

Mexican American political movements, which had always been somewhat politically divided over whether to promote American assimilation or Mexican cultural heritage, assumed a decided ethnic orientation in the 1960s (Garcia 1985; Portes and Rumbaut 1996). The most radical of these was the Chicano Movement, which advocated a separatist, Chicano ethnic identity. In opposition to the separatist politics of the Chicano movement, class-based mobilizations emerged that promoted solidarity among Mexican Americans and Mexican nationals on both sides of the border (Garcia 1985). There was a surge of political activism in Mexican communities by community groups, politicians, and civil rights activists. By the beginning of the 1980s, there was a large, politically organized, and mobilized coalition of ethnic Mexican activists that won important political gains, including the election of Mexican Americans to state and federal offices for the first time (Garcia 1985; Portes and Rumbaut 1996).

At the height of Chicano militancy in 1969, President Richard Nixon established "National Hispanic Heritage Week." The inauguration of the category "Hispanic” submerged the particular history of Mexicans (as well as Puerto Ricans and other Spanish-speakers) into a broad and generic cultural group, subverting their particular political demands. "Hispanic" became a widely marketed and depoliticized group characterized by cultural attributes such as traditional values and family-orientation (De Genova and Ramos-Zayas 2003).

\section{0 - 1982: End of the Miracle}

As the 1960s drew to a close, Mexico’s economic miracle was facing serious challenges. The progress of the past three decades was tainted by growing inequalities between rich and poor, a stagnant agrarian economy, and the blight of urban poverty (Massey et al. 2002, 72). By 1970, Mexico owed 4.2 billion dollars to foreign debtors and was, once again, importing basic foodstuffs (Kirkwood 2000 191). Unemployment rose in both urban and rural sectors and by 1973 inflation reached 20 percent; when the government was forced to float the peso in 1976, it promptly lost half its value (Kirkwood 2000, 198). The discovery of large oil reserves in 1976 generated revenue and temporarily relieved the pressure of recession, but it simultaneously rendered Mexico more dependent on foreign oil markets (Cerrutti and Massey 2004; Kirkwood 2000).

A rapidly growing population, high levels of unemployment, and the peso's plunge contributed to sustained undocumented labor emigration throughout the 1970s. The social and human capital that the braceros had accumulated facilitated undocumented migration at the same time that the United States capped legal Mexican immigration at historically low levels (Massey et al. 2002). The number of INS apprehensions of undocumented immigrants (of whom the vast majority were Mexican) grew from one million in the 1960s to seven million during the 1970s (Hondagneu-Sotelo 1994:23). The demographic characteristics of migrants remained largely consistent with the earlier period. The vast majority of migrants was male and most came from the traditional sending states of Guanajuato, Michoacan, and Jalisco (Arias 2004; Cornelius 1989; Durand et al. 2001). Although women had begun migrating within Mexico, particularly to work in the maquiladora zones of the north (Fernandez Kelly 1983; Hondagneu-Sotelo 1994), there was only a small increase in female transmigrants between 1965 and 1975, which Massey

The Journal of Latino-Latin American Studies, Volume 3, Number 3, spring 2009, pp. 2-18 
et al. (2002:55) attribute to the reunification of wives and daughters of legalized braceros. While an estimated 28 million undocumented and 1.3 million documented Mexicans entered the United States between 1965 and 1986, over 23.4 million returned, indicating that Mexico-U.S. migration was still largely circular (Massey et al. 2002:45).

In spite of the economic interdependency between Mexican workers and U.S. businesses established by the Bracero Program, in 1965 the United States imposed immigration quotas on Mexico for the first time. Prior to the Hart-Cellar Act of 1965, the U.S. allowed an unlimited number of visa applications from Western Hemisphere countries; the 1965 act introduced an annual ceiling of 120,000 visas for the entire hemisphere (Golash-Boza 2009; Ngai 2004:261). Additional legislation passed in 1976 capped legal entries at 20,000 per country and closed a loophole in immigration law that had allowed undocumented immigrants with citizen children to legalize their status (Ngai 2004: 261). In other words, from 1965 to 1976, the number of Mexicans who could enter the United States legally dropped from an unlimited number to just 20,000 per year. As Golash-Boza (2009) points out, in light of the interdependence of Mexican workers and U.S. businesses, such restrictions were unrealistic in the 1960s and are even more so today.

During the 1970s the federal government also began to escalate attacks on Mexican immigrant workers and hold highly-publicized operations on the border (Massey et al. 2002). The imposition of these numerical limits, the tightening of legal residency standards, and the highly public nature of anti-immigrant campaigns served to recast a century-old labor pattern as "illegal" and to criminalize Latino immigrant workers (De Genova 2005; Massey et al. 2002; Ngai 2004:261; Suarez-Orozco and Suarez-Orozco 1995). Throughout the 1980s, 1990s, and the first decade of 2000, US immigration policy has become ever more oriented toward restriction and militarization.

Anti-immigrant campaigns became particularly virulent during the 1980s and 1990s (De Genova 2005; Massey et al. 2002). Following the passage of the Immigration Reform and Control Act (IRCA) in 1986, undocumented migration continued to rise, spurred on by the everexpanding social networks of migrants already working in the United States (especially the 2.3 million who were legalized under IRCA provisions) (Massey et al. 2002). Under public pressure, the government responded with a series of border "Operations" during the 1990s that "blockaded" sections of the Mexico-U.S. border with fences, floodlights, motion detectors, and other detection technology (Massey et al. 2002; Orrenius 2004). Although these operations had no measurable long-term effect in deterring undocumented migration, their symbolic message was powerful. The highly-publicized campaigns of Operation Blockade (1993), Gatekeeper (1994), Safeguard (1995, 1999), Hold-the-Line (1997), and Rio Grande (1997) probably did more to create an iconic "Mexican/illegal alien" identity than anything that had come before. Meanwhile, increasingly restrictive immigration policies cut the number of legal entries for Mexicans and denied undocumented workers access to public services, even for those (around 62 percent) who paid taxes (Maiello and Ridgway 2006; Massey et al. 2002).

This period represents a shift in migration patterns in three important ways. First, as economic conditions in Mexico deteriorated, the reliance on U.S. labor markets for wage earners increased. Second, networks established during the Bracero program rendered migration patterns largely self-sufficient and resistant to immigration restrictions. Third, the movement of Mexican labor over the border was met with increasingly restrictive policies and border militarization projects, producing a highly selected-for Mexican labor force characterized by illegal status.

The Journal of Latino-Latin American Studies, Volume 3, Number 3, spring 2009, pp. 2-18 


\section{2 - Present: Decades of Crisis}

In 1982, the price of oil fell and took the Mexican peso with it. The peso underwent a series of devaluations: from 10 pesos to a dollar in 1981, it sunk to 80 to a dollar in 1982 then 150 to a dollar in 1983; the peso further plummeted from 800 to a dollar in 1986 to 2,300 pesos to a dollar in 1987 (Kirkwood 2000, 202). Real wages fell by 25 percent between 1981 and 1983; inflation skyrocketed to 480 percent in 1982 and the real value of the minimum wage fell by 20 percent (Massey 1988, 407). The prices for essential agricultural inputs like feed, fertilizer, and fuel rose dramatically and agricultural production in the Bajío decreased (Cornelius and Martin 1993). Foreign capital fled as Mexico’s foreign debt mounted. Adding insult to injury, a 1985 earthquake devastated Mexico City, leaving 20,000 people dead and 200,000 homeless (Kirkwood 2000, 202-203). Mexico was in ruins, literally and financially. The U.S. government, the IMF, and World Bank stepped in, lending Mexico massive public funds to bail itself out of the crisis (Greider 1997; Kirkwood 2000).

New “technocratic" leadership responded by abandoning the centralized state-controlled economy established by Cárdenas and adopting the neoliberal policies of the United States. In 1986 the government began to privatize the economy, scale back government regulations, and integrate more fully in international markets (Cerrutti and Massey 2004; Greider 1997; Kirkwood 2000; Portes and Landolt 2000). Mexico sold off up to 85 percent of governmentowned industry to private investors in Mexico and abroad (Kirkwood 2000, 206). The administration of de la Madrid (1982-1988) joined the General Agreement on Tariffs and Trade (GATT), deregulated financial markets, relaxed trade barriers, and generally opened itself up to the global capital system (Cerrutti and Massey 2004; Greider 1997, 270; Kirkwood 2000). Entry into the global marketplace, reinforced and accelerated by the North American Free Trade Agreement in 1993, was supposed to rescue Mexico from its massive debts and allow the economy to modernize and prosper. Instead, the Mexican economy contracted once again in 1994 (Greider 1997). Burdened by overseas debt, the government was forced to devalue the peso, prompting global investors to withdraw their money from Mexico’s economy (about 25 billion USD total) and slashing the value of the peso in half (Greider 1997, 261). Interest rates skyrocketed from 15 to 130 percent, converting Mexico into a country of bad debtors (Greider 1997, 265). As the government eradicated price controls and subsidies for local producers, agricultural markets were flooded with cheap, mass-produced American grain. In 1995, Mexico imported nine million tons of grain from the United States, about one-third of its domestic consumption (Golash-Boza 2009; Greider 1997, 272). As a result, approximately two million Mexican farmers were forced out of agriculture and joined the rolls of mobile wage-seekers saturating Mexican cities and moving north over the border in search of work (Golash-Boza 2009).

The U.S. provided 20 billion dollars in bailout money to the Mexican economy, supplemented by an additional 30 billion supplied by the IMF and World Bank (Kirkwood 2000, 211-212). These financial arrangements, while they helped arrest Mexico's economic downslide, also rendered the Mexican government increasingly subordinate to the oversight of global institutions and to the United States. Mexico's dependence on intra-NAFTA trade and on the U.S. in particular has only grown in the last decade; NAFTA trade networks now supply over 80 percent of the market for Mexico's international trade (Centeno et al. 2005).

The peso crises of the 1980s and 1990s caused profound transformations in patterns of Mexico-U.S. migration. First, the demographic characteristics of Mexican migrants changed (Durand et al. 2001; Fussell 2004; Roberts et al. 1999). The peso crises converted migration from

The Journal of Latino-Latin American Studies, Volume 3, Number 3, spring 2009, pp. 2-18 
a selective strategy employed by a narrow demographic to a widespread strategy to combat a host of problems, including unemployment, low wages, high interest rates, high costs of living, rising crime in the cities, and out-competition in local markets. Whereas migrants before 1982 tended to be male, of working-age, and neither extremely poor or wealthy, during the 1980s and 1990s the proportion of migrant females, middle-class, indios from the south, and urban residents increased (Durand et al. 2001; Flores et al. 2004; Hondagneu-Sotelo 1994; Marcelli and Cornelius 2001). A growing number of women entered the labor market during this period, both out of economic necessity and because females are often preferentially hired in globalized lowwage production jobs (between 75 and 90 percent of workers in the maquiladora zones are female) (Hondagneu-Sotelo 1994, 11; Fernandez Kelly 1983). Also, the Immigration Reform and Control Act (IRCA) of 1986 legalized 2.3 million Mexican immigrants, many of whom sent for their wives under IRCA's family reunification policy (Cornelius and Martin 1993). The proportion of females who emigrated without documents rose, more than doubled from 11.1 percent in 1965-1969 to 27.8 percent by 1990-1995 (Cerrutti and Massey 2004).

The social networks that Mexican transmigrant workers, built steadily for a century, now linked not only rural areas and small towns, but large metropolitan areas to potential jobs in the United States (Roberts et al. 1999). The devastation wreaked by the crises penetrated all sectors of the Mexican economy. It reduced the quality of living standards of urban and rural Mexicans and cut across middle- and working-classes (Kirkwood 2000; Roberts et al. 1999). Migration from the cities increased, stimulated by rising interest rates and bolstered by the diffusion of transnational social networks into urban areas (Flores et al. 2004; Portes and Rumbaut 1996). While the traditional sending states of Guanajuato, Michoacan, and Jalisco accounted for over half of Mexicans living in the U.S. in 1980, by 1992 that number had been reduced to a third (Arias 2004). In contrast, rates of international outmigration from the southern states of Oaxaca, Chiapas, and Guerrero rose (Cohen 2004; Cornelius 1989; Marcelli and Cornelius 2001). By 2000, 34 percent of households in Oaxacan communities had at least one member working in the U.S. (Cohen 2004, 63).

The second major change in recent Mexican migration involves settlement in the United States. As the strategy and composition of migration changed, so did the tendency for migrants to settle permanently in the United States (Cornelius 1989; Marcelli and Cornelius 2001; Durand et al. 2001). This has been attributed to three main factors: One, until 1982, Mexico-U.S.

migration tended to be seasonal and temporary, dominated by circular flows from the agricultural regions of west-central Mexico to the agricultural fields of California and Texas. Mexico's economic decline permanently depressed agricultural activity for Bajío farmers; this factor, combined with a greater tendency for migrants to attain year-round jobs in U.S. cities, has converted migration from a seasonal strategy for income diversification to a permanent strategy for subsistence (Cornelius and Martin 1993). Two, militarization of the Mexico-U.S. border has rendered unauthorized crossings dangerous and costly, providing further discouragement to move around (Massey et al. 2002). Finally, the increasing proportion of migrant women promotes settlement, not only because they tend to bring children (thus multiplying the costs and dangers of unauthorized crossings), but also because they forge social ties in the community, tend to be employed in permanent jobs, and are more likely to make use of institutionalized public and private assistance (Hondagneu-Sotelo 1994).

The third major shift involves the demographic characteristics of new migrants. New migrants are more diverse in both, geographic origin and in their choice of U.S. destination. Recent migrants have increasingly avoided traditional destination states such as California and

The Journal of Latino-Latin American Studies, Volume 3, Number 3, spring 2009, pp. 2-18 
Texas (probably due in part to oppressive anti-immigrant legislation in these regions) and have spread across the country. Between 2000 and 2005, for example, Georgia, South Dakota, South Carolina, and New Hampshire saw increases in the foreign-born population of 38.1 percent, 39.9 percent, 49.9 percent, and 50.8 percent, respectively, while Texas saw a 23.3 percent increase and California only a 9.5 percent increase during the same period (Pew Hispanic Center 2006b). The distribution of migrant workers across the suburban and rural United States has been a factor in widespread xenophobia and increased support of localized anti-immigrant laws in suburbs and small towns.

Fourth, there have been steady changes in the occupational distribution of transmigrant labor. The numbers of transmigrants working in agriculture has steadily decreased and has been overtaken by service industries such as food and beverage service, construction, and building and grounds maintenance as the principal employers of Mexican workers (Cerrutti and Massey 2004; Pew Hispanic Center 2006b). The labor force participation rates of Mexicans are quite high, 87.5 percent for undocumented workers who arrived between 1980 and 1990, compared to 74.4 percent for the total U.S. population (De Genova and Ramos-Zayas 2003, 61). Nevertheless, at over 30 percent, the poverty rates of undocumented Mexican workers triple the average of all Americans (De Genova and Ramos-Zayas 2003, 61).

Finally, after years of steady increases, the number of undocumented immigrants entering the United States from Mexico rose dramatically following the peso crises. According to Passel and Suro (2005), unauthorized Mexican migration rose 30 percent during the 1990s, peaked in 1999-2000, and has declined some ever since. For the whole decade of the 1980s, an estimated 1.8 million undocumented migrants arrived from Mexico. That number jumped to 4.9 million during the 1990s. An additional 4.4 million undocumented Mexicans arrived between 2000 and 2005 (Pew Hispanic Center 2006a). Increasing entries combined with reduced return migration has yielded an estimated population of approximately 12 million undocumented Mexicans currently living in the U.S. (Pew Hispanic Center 2006a). As the U.S. economy undergoes its most serious contraction in over 20 years, there is considerable speculation over whether the number of unauthorized migrants in the U.S. will decline, remain steady, or continue to increase.

\section{Politics of Exclusion}

Increases in the number of undocumented Mexican workers in the United States are only partially due to increases in the absolute number of people who move from Mexico to the United States. After all, transnational movement needn’t be “illegal.” Policies that restrict transnational labor - in the form of caps on visas, the tightening of border zones, and militaristic raids on workplaces - as they decrease restrictions on all other aspects of production are all but certain to produce a large and growing undocumented population. This glaring paradox has led many scholars to suggest that the mismatch of U.S. immigration policy to the realities of global capitalism is not accidental. But why would legislators intentionally support immigration policies that produce "illegal" immigration?

One influential paradigm holds that assigning illegal status to a segment of workers helps differentiate the labor force, producing a large population of workers who will toil for low wages and little security in America's expansive service economy (Basch et al. 1994; De Genova 2005; Cordero-Guzman, Smith, and Guarnizo 2001; Hondagneu-Sotelo 1994; Massey et al. 2002; Portes and Walton 1981; Sassen-Koob 1981). According to this perspective, undocumented labor "is not just any labor;" it is an important type of labor with a distinct role in global capitalist economies. Undocumented immigrant labor is cheap and flexible and can be used to suppress

The Journal of Latino-Latin American Studies, Volume 3, Number 3, spring 2009, pp. 2-18 
general wages and undermine efforts to unionize labor. Furthermore, characteristics like work ethic, diligence, and tractability can be enforced by the conditions of undocumented status (De Genova and Ramos-Zayas 2003). The "illegalization" of transmigrant workers keeps them in a permanent state of political vulnerability and economic insecurity and thus ensures their continued willingness to work at the bottom of the labor market (Basch et al. 1994; De Genova 2005; Massey et al. 2002; Portes and Walton 1981; Sassen-Koob 1981). A large, vulnerable lowwage work force generates big profits for American businesses that often have powerful lobbyists in Washington, D.C.

Accordingly, a prolonged “crackdown” on illegal immigration has become big business for important sectors of the U.S. political economy. In a 2009 article, Tanya Golash-Boza explores the persistent failure of U.S. immigration policy by asking who benefits from sustained undocumented immigration. She argues that the undocumented status of transmigrants benefits at least three groups: politicians who win votes by inciting fear of undocumented immigrants among their constituents, media pundits who boost ratings by railing against "illegal aliens," and contractors who profit from immigration law enforcement expenditures. This "confluence of interests,” Golash-Boza argues, helps explain why U.S. politicians doggedly persist in enacting immigration policies that have been proven to fail.

Yet, many U.S. politicians continue to assert that the weak Mexican economy is the main cause of undocumented migration from Mexico. An interpretation that locates the root cause of undocumented transmigration in putative underdevelopment of the Mexican economy not only negates the complicity of neoliberal development (promoted by the U.S.) in generating and sustaining transmigrant flows, but also ignores the demand for undocumented labor in important sectors of U.S. society. Most importantly, such a misinterpretation intensifies the marginalization of Mexican immigrants and undermines their claims to rights in the United States.

At the turn of the twenty-first century, legal, social, and economic marginalization of Mexican immigrants in the United States has serious implications for Mexican workers and U.S. Latinos alike. Proposed anti-immigrant legislation in 2004, 2005, and 2006 sparkled a serious wave of anti-immigrant sentiment and galvanized an unprecedented mobilization of support for immigrants (Campo-Flores 2006; Flores-Gonzalez et al. n.d.; Swarns 2006). As the intensity of immigration debates rose throughout the country in early 2006, so did the number of Americans who report immigration as the biggest problem facing the nation - up five-fold from 2 percent in November of 2005 to 10 percent in May of 2006 (Pew Hispanic Center 2006). While the American public is nearly evenly split on most major issues of the immigration debate, a significant majority see illegal immigration as a very serious problem (Pew Hispanic Center 2006c; Tumulty 2006). Furthermore, the politicization of immigration appears to have increased the vulnerability of immigrants in particular, and Latinos in general, to discrimination and hate crimes. Surveys of Latinos in 2006 reported that the majority (54 to 76 percent) perceive a rise in discrimination as a result of immigration policy debates (Campo-Flores 2006; Suro and Escobar 2006). In fact, federal crime statistics report a 40 percent jump in attacks on Latinos in the U.S. from 2003 to 2007, prompting the Mexican American Legal Defense and Educational Fund (MALDEF) to petition the U.S. Senate for stronger hate crime legislation (Urbina 2009).

\section{Conclusion}

The Journal of Latino-Latin American Studies, Volume 3, Number 3, spring 2009, pp. 2-18 
The case of Mexican labor migration to the United States effectively demonstrates how international economic relations, transnational politics, and the social relations of workers together generate and direct migratory patterns. In particular, neoliberal development in Mexico - helped along by its northern neighbor - has undermined the self-sufficiency of Mexican workers and agrarians alike, compelling them to become mobile wage seekers. The demand for low-wage workers in U.S. industries has pulled Mexican workers northward, giving direction to a transnational movement of labor that is now more than a century old.

In the United States, a combination of border militarization and anti-immigrant policies has not reduced the flow of unauthorized migration, but has “illegalized" it, legitimizing exploitation of transmigrant workers by making access to political, economic, and social resources a right of citizenship. U.S. immigration policies produce, reinforce, and reify the distinction between citizen and immigrant while selective enforcement of the border, and the globalization of all aspects of production except for labor, renders the continued migration of labor all but certain. This case study further shows that political discourse that treats undocumented immigration as "Mexico's problem," an anomaly that developed independently of U.S. policy, is at best poorly informed and at worst flatly dishonest. Such interpretations absolve U.S. policy-makers from responsibility in encouraging, sustaining, and directing undocumented migrant flows. Furthermore, they justify the marginalization of undocumented workers, contributing to their persistent exploitation, discrimination, and political exclusion from U.S. society. 


\section{References}

Arias, Patricia. 2004. Old Paradigms and New Scenarios in a Migratory Tradition: U.S. Migration from Guanajuato. In Crossing the Border: Research from the Mexican Migration Project, edited by Jorge Durand and Douglas Massey. New York: Russell Sage Foundation.

Arizpe, Lourdes. 1980. Cultural Change and Ethnicity in Rural Mexico. In Environment, Society, and Rural Change in Latin America, edited by David Preston. New York: John Wiley and Sons.

Basch, Linda, Nina Glick Schiller, and Szanton Blanc Cristina. 1994. Nations Unbound: Transnational Projects, Postcolonial Predicaments, and Deterritorialized Nation-States. Amsterdam: Gordon and Breach Science Publishers.

Calavita, Kitty. 1994. U.S. Immigration and Policy Responses: the Limits of Legislation. In Controlling Immigration, edited by Wayne Cornelius, Philip Martin, and James Hollifield. Stanford: Stanford University Press.

Campo-Flores, Arian. 2006. America's Divide. Newsweek, April 10.

Cardoso, Lawrence A. 1980. Mexican Emigration to the United States 1987-1931. Tucson: The University of Arizona Press.

Cardoso, Lawrence A. 1983. Review: Across the Border: Rural Development in Mexico and Recent Migration to the United States. The American Historical Review 88:226-227.

Centeno, Miguel, Sara Curran, John Galloway, Paulette Lloyd, Suresh Sood, and Abigail Cooke. 2005. The Rise of NAFTA. Center for Migration and Development.

Cerrutti, Marcela, and Douglas Massey. 2004. Trends in Mexican Migration to the United States, 1965 to 1995. In Crossing the Border: Research from the Mexican Migration Project, edited by Jorge Durand and Douglas Massey. New York: Russell Sage Foundation. Cohen, Jeffrey H. 2004. The Culture of Migration in Southern Mexico. Austin: University of Texas Press.

Cornelius, Wayne. 1981. Mexican Migration to the United States. Proceedings of the Academy of Political Science 34:67-77.

Cornelius, Wayne. 1989. Impacts of the 1986 US Immigration Law on Emigration from Rural Mexican Sending Communities. Population and Development Review 15:689-705.

Cornelius, Wayne, and Philip Martin. 1993. The Uncertain Connection: Free Trade and Rural Mexican Migration to the United States. International Migration Review 27:484-512.

De Genova, Nicholas, and Ana Y. Ramos-Zayas. 2003. Latino Crossings: Mexicans, Puerto Ricans, and the Politics of Race and Citizenship. New York: Routledge.

Durand, Jorge, Douglas Massey, and Rene Zenteno. 2001. Mexican Immigration to the United States: Continuities and Changes. Latin American Research Review 36:107-127.

Fernandez-Kelly, M. Patricia. 1983. For We Are Sold, I and My People: Women and Industry in Mexico's Frontier. Albany: State University of New York Press.

Flores, Nadia, Ruben Hernandez-Leon, and Douglas Massey. 2004. Social Capital and Emigration from Rural and Urban Communities. In Crossing the Border: Research from the Mexican Migration Project, edited by Jorge Durand and Douglas Massey. New York: Russell Sage Foundation.

Foster, George. 1979 [1967]. Tzintzuntzan: Mexican Peasants in a Changing World. Prospect Heights: Waveland Press.

The Journal of Latino-Latin American Studies, Volume 3, Number 3, spring 2009, pp. 2-18 
Fussell, Elizabeth. 2004. Sources of Mexico's Migration Stream: Rural, Urban, and Border Migrants to the United States. Social Forces 82:927-967.

Gamio, Manuel. 1929. Observations on Mexican Immigration Into the United States. Pacific Affairs 2:463-469.

Garcia, Mario T. 1985. La Frontera: The Border as Symbol and Reality in Mexican-American Thought. Mexican Studies/Estudios Mexicanos 1:195-225.

Golash-Boza, Tanya. 2009. A Confluence of Interests in Immigration Enforcement: How Politicians, the Media, and Corporations Profit from Immigration Policies Destined to Fail. Sociology Compass 3: 293-294.

Greider, William. 1997. One World, Ready or Not: The Manic Logic of Global Capitalism. New York: Simon \& Schuster.

Gutierrez, David G. 1995. Walls and Mirrors: Mexican Americans, Mexican Immigrants, and the Politics of Ethnicity. Berkeley: University of California Press, Berkeley.

Hondagneu-Sotelo, Pierrette. 1994. Gendered Transitions: Mexican Experiences of Immigration. Berkeley: University of California Press.

Kirkwood, Burton. 2000. The History of Mexico. New York: Palgrave.

Krauze, Enrique. 1997. Mexico: Biography of Power. New York: Harper Perennial.

Marcelli, Enrico, and Wayne Cornelius. 2001. The Changing Profile of Mexican Migrants to the United States: New Evidence from California and Mexico. Latin American Research Review 36:105-131.

Maiello, Michael, and Nicole Ridgway. 2006. Alien Nation. Forbes, April 10.

Massey, Douglas. 1988. Economic Development and International Migration in Comparative Perspective. Population and Development Review 14:383-413.

Massey, Douglas, Joaquin Arango, Graeme Hugo, Ali Kouaouchi, Adela Pellegrino, and J. Edward Taylor. 1998. Worlds In Motion: Understanding International Migration at the End of the Millennium. Oxford: Clarendon Press.

Massey, Douglas, Jorge Durand, and Nolan J. Malone. 2002. Beyond Smoke and Mirrors: Mexican Immigration in an Era of Economic Integration. New York: Russell Sage Foundation.

Menchaca, Martha, and Richard Valencia. 1990. Anglo-Saxon Ideologies in the 1920s-1930s: Their Impact on the Segregation of Mexican Students in California. Anthropology \& Education Quarterly 21:222-249.

Organizing For America. Organizing on the Issues: Immigration. Blueprint for Change: Immigration Video. http://www.barackobama.com/issues/

Passel, Jeffrey, and Roberto Suro. 2005. Rise, Peak, and Decline: Trends in U.S. Immigration 1992-2004. Pew Hispanic Center.

Pedraza, Silvia, and Ruben G. Rumbaut. 1996. Origins and Destinies: Immigration, Race, and Ethnicity in America. New York: Wadsworth Publishing Company.

Pew Hispanic Center. 2006a. Recently Arrived Migrants and the Congressional Debate on Immigration. Electronic Document.

Pew Hispanic Center. 2006b. Foreign Born at Mid-Decade. Electronic Document.

Pew Hispanic Center. 2006c. The State of American Public Opinion on Immigration in Spring 2006. Electronic Document.

Portes, Alejandro. 2004. The New Latin Nation: Immigration and the Hispanic Population of the United States. Princeton: Princeton University Press.

The Journal of Latino-Latin American Studies, Volume 3, Number 3, spring 2009, pp. 2-18 
Portes, Alejandro, and Patricia Landolt. 2000. Social Capital: Promise and Pitfalls of its Role in Development. Journal of Latin American Studies 32:529-547.

Portes, Alejandro, and John Walton. 1981. Labor, Class, and the International System. New York: Academic Press.

Preston, Julia, and Samuel Dillon. 2004. Opening Mexico: the Making of a Democracy. New York: Farrar, Straus and Giroux.

Ngai, Mae. 2005. Impossible Subjects: Illegal Aliens and the Making of Modern America. Princeton: Princeton University Press.

Orrenius, Pia. 2004. The Effect of U.S. Border Enforcement on the Crossing Behavior of Mexican Migrants. Crossing the Border: Research from the Mexican Migration Project, edited by Jorge Durand and Douglas Massey. New York: Russell Sage Foundation.

Roberts, Bryan R., Reanne Frank, and Fernando Lozano-Ascencio. 1999.Transnational migrant communities and Mexican migration to the US. Ethnic and Racial Studies 22: 238-266.

Roberts, Kenneth D. 1982. Agrarian Structure and Labor Mobility in Rural Mexico. Population and Development Review 8:299-322.

Sassen-Koob, Saskia. 1981. Towards a Conceptualization of Immigrant Labor. Social Problems 29:65-85.

Suro, Roberto, and Gabriel Escobar. 2006. 2006 National Survey of Latinos: the Immigration Debate. Pew Hispanic Center.

Suarez-Orozco, Carola, and Marcelo Suarez-Orozco. 1995. Transformations: Immigration, Family Life, and Achievement Motivation Among Latino Adolescents. Stanford: University of Stanford Press.

Swarns, Rachel L. 2006. Growing Effort to Influence U.S. Policy. The New York Times, Tumulty, Karen. 2006. Should They Stay or Should They Go? Time, April 10.

Urbina, Ian. 2009. After Pennsylvania Trial, Tensions Simmer Over Race. The New York Times, May 16.

Weaver, Frederick Stirton. 2000. Latin America in the World Economy: Mercantile Colonialism to Global Capitalism. Boulder: Westview Press.

Wright, Angus. 1990. The Death of Ramon Gonzalez: the Modern Agricultural Dilemma. Austin: University of Texas Press.

The Journal of Latino-Latin American Studies, Volume 3, Number 3, spring 2009, pp. 2-18 